\title{
Perspectives on the role of business in social innovation*
}

\author{
Fabien Martinez ${ }^{1}$ \\ Patrick O'Sullivan ${ }^{2}$ \\ Mark Smith ${ }^{2}$ \\ Mark Esposito ${ }^{2}$
}

\author{
${ }^{1}$ Queen Mary, University of London \\ ${ }^{2}$ Grenoble Ecole de Management
}

\begin{abstract}
Purpose

This article examines the conceptual construct of social innovation in business as distinct from social innovation implemented by civil society and the state. The general absence of sustained research and analysis of this phenomenon, and the dominance of grey and policy-oriented literature, mean that a broadly accepted definition of how social innovation theorises the changing role of business in society is missing.

\section{Design/methodology/approach}

We conducted an integrative review of the representative literature on social innovation. The analysis focused on the key arguments made about the involvement of business actors in processes of social innovation and interweaved in this study to build a logically coherent definition of what social innovation in business means for the bulk of those who write and speak about it today. The scope of the literature review was expanded by integrating insights from the extant 'business in society' and social innovation literatures, thereby adding clarity to our conceptualisation.
\end{abstract}

\section{Findings}

The findings indicate that social innovation is best understood as a process driven by human relations, morality and creative capacity breaking routines and path dependencies. It fundamentally relies on the socially constructed dynamics between business and social actors who carry ideas, focus their energies, mobilise competences and create new complementarities to tackle social problems. Economic gain, in this approach, is at best an outcome of social innovation, not its engine.

\section{Originality/value:}

What this literature review unveils that is unique about social innovation, and contributes to an enrichment of the 'business in society' debate beyond the business case and win-win scenarios depicted by most scholars in this field, is that it best manifests itself as an informal social 
process that comes into existence at the margins of conventional ways of thinking and organising business activities. Business actors involved in social innovation are framed as selfdirected and self-organised around the moral purpose of fostering social progress.

Keywords: social innovation, business sustainability, shared value creation, social progress, literature review.

\section{Introduction: The challenge of social innovation in business}

This article is intended as a contribution to the ongoing conceptual development of corporate social innovation. The concept of social innovation challenges business and management thinkers and practitioners to pursue solutions involving a better alignment of business performance goals with social progress. Within this view, business organisations can be engaged problem solvers, proactive advocates of inclusiveness and proactive social entities, embedded in the communities in relation to which they operate. Studies of corporate social innovation arguably belong to a tradition of business and management scholarship that seeks to understand the forms by which the business community may engage more substantively to address social and environmental problems. The late Professor Nigel Roome was a fervent contributor to this field, writing about social innovation as innovation that "has the potential to effect change in conventional [public and private] sectors of the economy and society" (2013, p. 299). Roome's conception of change was seen through the lens of sustainable development, an important tenet of which is the idea of mobilising all actors in society that participate in economic and social development. That led Roome to call for the bolder participation of the business community in a "grand form of social innovation" (2013, p. 306). The present study seeks to contribute to the research agenda that responds to this call by addressing the challenge of 'social innovation in business' separately to that of social innovation implemented by civil society and the state.

Business has traditionally been regarded as an engine of innovation, and through that a driver of industrial and economic growth (Roome, 2013). Typical forms of business innovation include technological innovations (i.e., new or improved products and processes) and organisational innovations (i.e., changes to the firm's strategies, structures and operations) (Pol $\&$ Ville, 2009). The failure of these forms of innovation to offer solutions to pressing societal issues (e.g. poverty, social exclusion, climate change), coupled with a desire to promote new ways of doing things, yielded a growing interest in understanding the role of business as an 
actor (if not an engine) of social innovation. However, we found that the existing literature lacks consistent and comprehensive research regarding the conceptual constructs of social innovation in business and it has been incapable of generating the empirical evidence that would support its widespread adoption (Mulgan, Tucker, Ali, \& Sanders, 2007). Djellal and Gallouj (2012) explain that firms tend to implement socially innovative activities through informal processes and interactions that can hardly be evaluated against the traditional indicators for measuring innovation, such as $R \& D$ and patents registration.

The phenomenon of social innovation is essentially based on a visionary view of business organisations as capable of becoming engaged social problem solvers. A socially innovative business may be defined as an active contributor to the enhancement of the governance capacity of a society (European Commision, 2011). It can be persuaded to abandon its overriding belief in the market as a superior mechanism for efficient allocation of resources and to develop instead a capacity to identify and find solutions to address unmet social needs. If we are to have a focus on social innovation as a key contributor to making business better contribute to society, some specifications and concrete propositions of what is meant by corporate social innovation are indispensable. The general absence of sustained research and analysis of this phenomenon, and the dominance of grey and policy-oriented literature, are holding back the conceptualisation and practice of social innovation (Howaldt \& Schwarz, 2010; Mulgan, 2006). Indeed social innovation seems to mean quite different things to different people (Gatignon, Gotteland, Haon, \& Zimmer, 2016). Hence there is the danger that in any critical debate or discussion of the topic protagonists may become embroiled in controversy or drift down irrelevant intellectual and practical blind alleys simply because of differences in the meaning of the term 'social innovation'.

In this article, we critically review representative research to articulate a comprehensive conceptualisation of social innovation as a distinctive activity for business organisations, rather than an undefined nuance of existing constructs. Social innovation is a subject that has recently gained momentum in 'business in society' literature, reflecting a change in the trend of this phenomenon and the way it is framed. But the literature to date remains often ambiguous as to the basic concept. We suggest therefore that a synthesis of the most representative literature to date as a prelude to theoretical clarification and greater precision will help researchers and practitioners get a better grasp of the concept of how it can contribute to an evolution of the 'business in society' debate. One might particularly wonder how the concept of social innovation can preserve its primary motivation of meeting social ends when it is applied by 
business agents who are generally supposed to work towards profit maximisation. This 'paradoxical' task is most commonly known in the literature as a core tenet of the shared value concept famously articulated by Porter and Kramer (2011). Crane, Palazzo, Spence, and Matten (2014) argued that the core ideas of the concept of 'shared value creation' had been allegedly covered in the social innovation literature long before its introduction by Porter ad Kramer. They notably explain that the social innovation literature assumes "that there are firms, or activities within firms, which deliberately follow social, environmental, or ethical objectives either exclusively or alongside economic ones" (Crane et al., 2014, p. 143). But their broader focus on a critique of the shared value concept means that they engaged rather superficially with the literature on the subject of social innovation. This observation is also reflected in Porter and Kramer's response to Crane et al. (2014) from which a discussion of the overlaps between the concepts of social innovation and shared value creation is conspicuously absent (Ennes, 2014). We are thus left with a void in our knowledge of the distinctive features of social innovation that enrich the 'business in society' debate. The present study serves as a useful resource to fill this void by synthesising some key tenets of the social innovation perspective and clarifying how it distinctively theorises the changing role of business in society, while providing sufficient context to develop social innovation research.

\section{Research method}

We draw upon the principles of an integrative literature review (Martinez, 2015; Torraco, 2005), and from there we seek to build a precise and logically coherent definition of what social innovation in business means. The first step in the process of developing a comprehensive search of the representative literature to date was to type the keywords 'social innovation' in 'Google Scholar' using citations to identify papers with the highest impact. Although Google Scholar is challenged by some with respect to the accuracy of the information it collects (e.g., Bauer \& Bakkalbasi, 2005; Beall, 2014; Serenko, 2015), these data have the advantage of offering recent and relatively complete citation numbers because it does not limit references to a list of accepted journals, but also includes conference papers and other references. The popularity of Google Scholar as an academic literature search engine also means these data are indicative of the publications that are more likely to be read and cited. Therefore, they represent a reliable indicator of a publication's true impact. We selected documents that include the term 'social innovation' in the title and that have generated at least 200 citations in other scholarly literature. As a result, our sample consists of articles having 240 citations or more as of 
September 21, 2016. Table 1 summarises and ranks the selected articles according to their number of citations found.

[Insert Table 1 about here]

The selection of articles does not account for methodological quality as a criterion since we do not aim to examine the strength and validity of the claims made. The focus is rather on the meaning of social innovation, and the way it is conceptualised, and so the type of evidence advanced or the rigour of the method are not our primary concern. We add that our decision to select the most representative literature, without focusing on a specific discipline enables us to connect ideas that move across sectoral and disciplinary boundaries - social innovation being itself recognised as a theme that crosses disciplinary boundaries (e.g., Franz, Hochgerner, \& Howaldt, 2012; Moulaert, MacCallum, Mehmood, \& Hamdouch, 2013; Osburg \& Schmidpeter, 2013). Our intention is thus to engage with readers from various sectoral and disciplinary backgrounds - e.g. business managers and researchers, social entrepreneurs, designers, engineers, policy-makers, community developers, social and environmental activists, city developers, urban planners and neutral convenors (Murray, Caulier-Grice, \& Mulgan, 2010).

We conducted a content analysis of each piece of literature to extract the most relevant arguments both in favour of, and against, the practice of social innovation in business. The authenticity of the key ideas and themes that emerged from the analysis was verified through discussions between the authors, leading to their validation and/or refinement. Once we had achieved a satisfactory degree of convergence on the key arguments in the literature, we proceeded to a conceptual reasoning that exposes the knowledge that may have been taken for granted, hidden or omitted by previous research and which seeks to a bring greater precision to the concept of social innovation. This is achieved partly through conceptual reasoning and partly by integrating insights from the extant 'business in society' and social innovation literatures; thus adding clarity to the conceptualisation of social innovation and providing context for future research in this domain.

\section{Findings}

Our starting point for any conceptual clarification must be the existing literature on the subject of social innovation. The literature review reveals that, while there are some key elements in 
common, there are also significant variations in the usage of what remains an emerging and vaguely defined term ${ }^{2}$. One recurring element however is the attempt at capturing the catalysts for, and the impediments to, the participation of business actors in social innovation. We specifically analyse how the literature explains what drives or impedes the involvement of business in the development of new ideas that simultaneously meet unmet social needs and create new social relationships or collaborations. These 'new ideas' are iteratively discussed in the literature as products, services and / or models. Table 2 synthesises the core arguments made in the literature, and specifies the type of ideas that are pursued (i.e., focus of innovation). We use the ranks assigned in Table 1 to identify the articles and indicate their relative weight.

[Insert Table 2 about here]

\section{Toward a human-centric approach to social innovation}

Kanter (1999) defined the concept of social innovation as a process where companies view community needs as opportunities to develop ideas and demonstrate business technologies, to find and serve new markets, and to solve long-standing business problems. The approach requires the development of a business agenda that does not consider social problems as objects of charity but rather as opportunities for learning and for business development. Kanter (1999) goes on to discuss examples of the successful social innovation partnerships involving Bell Atlantic, Marriott International, IBM and Bank Boston to demonstrate the viability of this approach. These companies are argued to have constructed a solid business plan that relies on shared resource allocation to address a social problem. The framing used to describe these practices seems however problematic. Are these real social innovations? Might they not be alternatively framed as the outcome of the firms' engagement in processes of shared value creation that may not in itself be innovative? That also means to question if Kanter's (1999) view of social innovation, as a means to solve business problems, reflects how the concept is generally defined in the literature. One element that characterises the literature is its general emphasis on social innovation as a model, as opposed to the business product and/or service discussed by Kanter (1999) (cf. Table 2). A more critical analysis is necessary to clarify the precise meaning of social innovation, what motivates business involvement, how it co-exists with economic profitability and what are its distinctive characteristics.

The work of Mulgan et al. (2007) identifies three main antecedents to social innovation in business: (1) bold individuals or leaders who seek to enact their moral agency, to encourage 
and reward successful innovation, and who can straddle different fields, (2) activist movements of change with ideological precepts carried by individuals who are able to diffuse them in organisational apparatus, and (3) market dynamics (e.g. micro-finance, fair trade, open source software or organic food) and other organisational incentives. The first two factors are indicative of a broader trend in the literature in which social innovation is understood as a process driven by human relations, morality and creative capacity breaking routines and 'path dependencies'. Our analysis thus challenges the idea that purely market-based solutions can be engines of social innovation. We will instead place an emphasis on the role of purposive motivated human agents who are self-directed and self-organised in developing socially innovative ideas.

\section{The economic and social case for social innovation}

Two main reasons are advanced in the literature to justify a firm's engagement in social innovation: (1) the economic case, there are rising demands for types of economic growth that enhance rather than damage human relationships and well-being (Mulgan et al., 2007); and (2) the social case, the capacity of firms to connect actors and resources together to elaborate better solutions, calibrated to address a social need or problem, and for which the value created (benefits) accrues primarily to society as a whole rather than to private individuals and organisations (Phills, 2009). However, the barriers to such engagement are high. The competitive pressures and potential profitability that drive innovation in commercial markets are blunted or absent in the social field. Institutional support and funds devoted to social innovation are generally deemed insufficient (Fairweather, 1967; Mulgan, 2006) and ineffective as a way of producing innovation and transformation (Kanter, 1999), tending to rely on a limited public and philanthropic support (Phills, 2009). The social case for social innovation is thus turned by some into an idealistic aspiration that cannot be made to blend with market-based principles. It follows that the implementation of socially innovative ideas, whether motivated by the economic or social case, is generally impeded by the incapacity of most markets and environments for decision-making to be open for social solutions (Phills, 2009).

Social innovation as a social process that challenges a narrowly financial strategic focus...

The lack of congruence between traditional business models and social innovation leads McElroy (2002) to argue that social innovation is a self-organising process, not a managed 
process. One implication is that the involvement of business in social innovation does not tend to proceed from a purely managerial logic based on profit maximisation. Rather, the practice of social innovation in firms is made possible by a social process triggered at the margins. This process is fundamentally driven by an inspirational and emulative effect that involves morallyengaged and motivated individuals in a dynamic and interactive flow of ideas, values, capital, and talent across sector boundaries (Mulgan, 2006). The effect may be produced by individuals inside business organisations who are placed in a situation of increased proximity with the roots of a social problem as they engage with those experiencing the problem (Fairweather, 1967; Murray et al., 2010). They will thus develop their knowledge of unmet needs, and the challenges being addressed, to precisely evaluate the combination of financial and human resources required to solve the social problems. The far-reaching potential of this phenomenon led McElroy to refer to it as the most valuable form of intellectual capital "because it underlies a firm's fundamental capacity to learn, innovate and adapt" (2002, p. 30).

The social innovation journey described by some authors (e.g. Kanter, 1999; McElroy, 2002; Mulgan, 2006) from a collective and cross-sectoral emulation effect motivated by a farsighted ethics geared to the production of business profits raises a number of concerns. Firstly, it overlooks the impact of the possible tensions between the demonstration of positive social changes and the production of sustained economic results. Positive social changes involve the consumer as a proactive player, and more generally individuals as "competent [and subjective] interpreters of their own lives and competent solvers of their own problems" (Mulgan, 2006, p. 150). Companies may thus be involved only in an indirect way - such as providing financial and technological resources. By contrast, economic results in a generally materialist consumer society stem from a system in which the consumer is a passive player. Companies use their operating funds to sustain this profitable system and are systematically looking for an economic gain. If an economic gain may not always be guaranteed to the provision of products and services for social good, presenting it as the engine of social innovation would mean to commit an ontological fallacy - as suggested by Pol and Ville (2009). Secondly, the orientation of this journey toward business profitability is also likely to trigger some forms of discrimination against social innovation ideas and projects for which business returns are not necessarily immediate nor evident and that would hence not get the necessary push from inception to impact. It may result in the co-option of social innovation by business concerns and the translation of social innovation as a traditional business tool for economic growth that perpetuates traditional boundaries between production, consumption and communities. The 
development of a co-option effect of this kind may ultimately reduce the capacity of social innovation to facilitate the mobilisation of networks and the concomitant creative blending and recombination of disparate elements and ideas (Mulgan, 2006; Murray et al., 2010).

\section{....and supports the idea of a human quest for desirable social outcomes}

Brown and Wyatt (2010) and Mumford (2002) argue that business can best use its potential as a source of social innovation if it bases decision-making and action-taking upon a substantively more human-centric approach. This implies that a firm's human capital is mobilised toward a desired social end goal. Individuals are thus willing to transcend institutional boundaries and bring about new forms of relationships, collaborations and motivating connections with social actors in local communities, governments and other non-profit sectors (Phills, 2009). Mulgan et al. (2007) and Murray et al. (2010) converge on the argument that socially innovative ideas brought about by an individual or a group of individuals go through a staged process to eventually become formally embedded in the set of activities of a firm, in ways that may yield organic growth. Corporations can then play an important part in the process of grooming ideas to scale, because they have the managerial and financial capacities to support the development of the new combinations of resources and social relationships (Howaldt \& Schwarz, 2010; Mulgan et al., 2007). Their role in the social innovation system is to link together people, ideas, money and power.

There is a wide range of modes and methods that business actors can contemplate and experiment with to integrate socially innovative activities with existing business models (Fairweather, 1967; Howaldt \& Schwarz, 2010; Mumford, 2002). One specific example stems from the work of Phills (2009) who observed that socially innovative business agents generally work with intermediaries, local partners who serve as cultural guides and make introductions to communities, which contributes to build credibility and ensure understanding. In more generic terms, the literature review suggests that ideas are to be scaled in a way that ensures the financial sustainability of the projects, with business methods, structures of accountability, governance and ownership that resonate with the social mission, not merely the potential for financial profitability (Murray et al., 2010). For instance, a social innovation perspective should yield a treatment of the question of whether it is good or bad to cut car use or to reduce the availability of low-cost flights, with arguments, evaluations and assessments that emphasise the social outcome (in this case among other things: avert pollution), not just the narrow profitability. Howaldt and Schwarz (2010) specify that the definition of what constitutes a 
socially desirable outcome is itself problematic insofar as it needs to account for the different purposes and interests of societal actors that do not necessarily align with business goals. Social innovation in this sense is to be approached as an activity that challenges conventional wisdom about sense-making rather than being relegated as an addendum to it. That is the only way in which it can be truly considered as a phenomenon capable of creating the conditions for systemic change (Murray et al., 2010) toward the global improvement of our living conditions.

We follow the stream of scholars who have argued that the potential of social innovation as a catalyst for change will be better served by a more substantive momentum of scholarly and practitioners' support of a human-centric approach (e.g., Brown \& Wyatt, 2010; McElroy, 2002; Murray et al., 2010). Here the emphasis is placed on the quality of relationships, repeated interactions, independent and self-directed learning of individuals, care and maintenance rather than one-off consumption. The literature review suggests that social innovation is one of many perspectives on the role of business in society that demands a Reconstructionist view on strategy formation. Within this view, market boundaries and industry structures are not static and can be reconstructed by the actions, beliefs and innovative skills of individual business agents and industry players. Evidence of this phenomenon led Kanter (1999) to write about the rise of a new paradigm for innovation founded upon a partnership between private enterprises and public interest that produces profitable and sustainable change for both sides.

This literature review reveals that social innovation best manifests itself as an informal social process at the margins of conventional ways of thinking and organising, rather than the business case and win-win scenarios depicted by Kanter (1999). Two elements captured in this review that demonstrate this point. The first element is that corporate financial investments and business acumen and methods deployed for social innovation can be a means to a social end, and not exclusively to financial payback. This makes possible the involvement of business in governance and ownership structures of socially-oriented projects, such as those of non-profit social entities - a movement trendily incentivised by favourable tax treatments lowering the cost of innovation (Murray et al., 2010). Secondly, the social innovation perspective frames human resources as independent and vibrant sources of value, inspiration and creativity. This characteristic may be found in business agents who are placed in situations in which they can enact their moral commitment to a social mission. They may demonstrate a capacity to engage in the co-development of a unique interplay of energising ideas that have the potential to leverage a firm's 'relational capital'. We refer to this phenomenon as a socially constructed 
process of change that mobilises business agents toward the creation of novel combinations of ideas and resources. In line with Brown and Wyatt, the process "allows for serendipity, unpredictability, and the capricious whims of fate - the creative realm from which breakthrough ideas emerge" (2010, p. 33).

Our review suggests suggest that social innovation primarily relies on the social constructions that take place between societal actors who carry ideas, focus their energies, mobilise competences and create new complementarities for a social cause. We recognise that other influential conceptual resources exist that have sought to improve our understanding of the socially constructed phenomena that characterise the changing role of business in society. Thus it is important to expand the scope of this literature review to engage with the extant 'business in society' and social innovation literatures, and that have made useful inferences about the meaning of social innovation. This will be a prelude to our precise conceptualisation of the phenomenon.

\section{Connecting with the extant literature: Towards a comprehensive definition of social innovation}

Concepts like social entrepreneurship, corporate social responsibility, creating shared value, sustainability and social innovation are firmly entrenched in modern business lexicon but these terms are often used loosely and interchangeably (Pol \& Ville, 2009). We believe that it is useful and important to focus on the precise meaning of such terms as a basis for asserting the distinctive features of the social innovation concept.

A review of the literature suggests that social innovation offers compelling potential for dealing with social problems as it is in the unique position of being driven by ideas and emulative creativity that are applicable to social problem-solving across sectors and businesses of all sizes. In contrast, the literature on social entrepreneurship refers to individuals who attempt to create a new entity that blurs the profit/non-profit boundary (Peattie \& Morley, 2008). Sustainability for its part is consistently tied to either areas of environmentalism or to the longevity of the organization or of the society in which it is implanted. While corporate social responsibility is a veritable catch-all to encompass a wide range of activities of organisations that have a social impact of any kind and that are deemed to be ethical (or philanthropic). The idea of creating shared value is broad and seeks to tie down and assess precisely the value created by an organisation for all of that organisation's stakeholders or for society at large from its activities; in short the organisation's contribution to social progress 
(SPI, 2015). What seems to bring together the concepts of social entrepreneurship, corporate social responsibility, sustainability and shared value creation is that they have been used to promote the business case for sustainability. The business case does not focus on social progress as much as it emphasises the idea of approaching social problems as economic opportunities (Martinez, 2014). If we advocate a distinctively more 'ethical' and sociallyoriented agenda for social innovation - in line with Moulaert, Martinelli, Swyngedouw, and Gonzalez (2005); we do not exclude that it might ultimately develop along a similar path.

Some scholars have raised concerns that social innovation may in fact include any types of innovations brought about by social actors (e.g., McElroy, 2002; Mulgan, 2006; Roome, 2004, 2012). To begin with, it should be noted that by the word 'social,' the literature generally refers to "socially esteemed goals" (Gillwald cited in Howaldt \& Schwarz, 2010, p. 25) as well as society-level problems, grievances, opportunities, and privileges, without naming any issue area specifically. Roome $(2004,2012)$ suggested that, in the context of social innovation, the word 'social' signifies that the process of innovation involves some actors who are not necessarily professional inventors and innovators. Rather it is located in a more social context involving a range of actors. The word 'social' in this view refers to the intent of innovation for example advancing a 'social' purpose. In line with Roome, Adams, Jeanrenaud, Bessant, Overy, and Denyer (2012) examined the sense of the word 'social' by referring to the notion of sustainability-oriented innovation in which economic, social and environmental considerations are integrated. Here, the word 'social' is set up in such a way that it has equal consideration alongside economic and environmental aspects - thus alluding again to the business case for sustainability. In this vein, we note that a number of scholarly contributions have taken social innovation to mean the creation and service of new markets (Kanter, 1999), the addition of value to our societies (Osburg \& Schmidpeter, 2013; Roome, 2013) or the integration of economic, social and environmental aspects of innovation (Adams et al., 2012). One criticism that can be levelled at these definitions lies in their overreliance on the narrowly commercial perspective. In our view, this posture overlooks other social innovations that do not provide net profits to the innovator, demonstrable via conventional and tangible performance indicators.

If social innovation is to avoid becoming vacuous as a term and becoming yet another conceptual component of the business case agenda, it must define some special feature that certain innovations consistently possess that is not present in other practical cases of innovation. What seems to be common to most of the definitions of social innovation we have reviewed is the reference either to the intention of the innovator (to try to solve a pressing social 
problem) or to the wider social consequences and effects of the innovation beyond the confines of the innovating organization. A social innovation therefore, we define as either an innovation motivated at root by a good intention; or one which produces good consequences benefitting a range of stakeholders in the wider society. Those with moral philosophical propensities will recognize in this definition a (deliberate) fudge between a Kantian intention-based definition of good actions and a utilitarian consequences-based definition.

It is not accidental that there should be a moral-philosophical undercurrent in our definition since that is present in the other definitions we have reviewed even if not explicitly stated: they all cover some aspect of bettering society — dealing with pressing social problems, innovations having a social purpose, or contributing to a sustainable development. The fact that there is a need at all to specify a socially good form of innovation is to acknowledge that, in general, not all innovations have been for the betterment of humankind. Thus strictly speaking there have been innovations which have had major social impacts and so could be described as "social" but where these effects are nefarious or even disastrous (cigarettes perhaps or certain sorts of weaponry) we would not normally want to describe these as 'social innovation' in the senses that term has been understood in the vast bulk of the literature. In effect, we are speaking not so much of 'social innovation' as of 'socially responsible innovation.'

One useful approach is to consider the counter factual: what would be the opposite of a social innovation; or specifically, what sort of innovation we would not want to label as 'social' in the sense of the literature. The diametric opposite of a social innovation would be an 'antisocial' innovation, which would be an innovation that generates one or many bad or morally unacceptable social consequences. We do not mean antisocial in its traditional sense of being antagonistic toward society or wanting to be apart from society, but rather an 'anti-social' innovation would be one that is planned or implemented either in spite of or without regard for the possible ramifications or negative externalities on society. For instance, a business innovation in food processing which involves addition of addictive and fattening ingredients to food might be considered anti-social if it leads to significant increases in obesity or the extraction of new sources of energy more polluting than existing carbon rich energies.

Of course, many innovations have potentially both beneficial and nefarious social consequences (think nuclear fission technology, Facebook), so it is probably quite rare to find unambiguously anti-social innovations. But the logical point is that social innovations, in contrast with anti-social innovations, are required to produce positively good social consequences in the societies in which they occur, and not just maintaining the status quo. A 
less dramatic contrast could be that between a social innovation and an innovation that, while we might not call it anti-social, we would not particularly want to call it social either. In effect, such an innovation would be morally and societally neutral, that is to say that it would produce consequences in social life which are neither particularly good nor bad per se. Sustainable supply chains notwithstanding, innovations that concern the world of art and fashion are often of this kind: they bring novelty and variety to human life without per se being good or bad or seeking to improve the human condition in societies, although they certainly can make a statement about it.

The purpose of considering these contrasts is to show that when we consider innovations that we might call anti-social or simply innovations that we would not want to call social, we arrive at the realization that what we are calling social innovations are those which have a moral purpose. This is to say that they aim to promote improvement in the human condition in the societies in which they are applied. It is in view of this realisation that we suggest that the term socially responsible innovation better captures the sense of the moral phenomenon than the simpler term social innovation.

From this point of view, socially responsible innovation becomes part of the broader contemporary movement towards more socially responsible business and the creation of shared value (Porter \& Kramer, 2011). Shared value is a response to the idea that businesses and their communities have a symbiotic relationship; to consistently innovate in ways that harm or feed off the limited capital or resources of societal stakeholders-including their health-is ultimately bad for business growth. To grow and keep that relationship flourishing is to be socially responsible, and shared value means that business must create social impact outside of its own walls. And so, in effect, a socially responsible innovation - product or process - is one that will consider its impact on the wider society with a view to promoting human well-being and so, in some sense, social progress. It will therefore be an innovation carried out in full cognisance of the impact which the innovation might have on the whole range of stakeholders of the business - such as its communities, customers, and employees - and will aim (if it is to be a 'social' innovation) to benefit some if not all of those stakeholders. ${ }^{1}$ Hence, a socially responsible innovation, just like a socially responsible business, is one which does not simply look to an increase in monetary profits as a model for value creation from the firm to the shareholders but rather one that looks to the wider potential value that is created across the whole array of the firms' stakeholders - to the shared value that is being created in the wider society. 
Of course socially responsible innovation may not represent the most profitable innovation opportunity at a given time. There will be times when, despite the undoubted reputational advantages that flow from being seen as a genuinely socially responsible in business, being socially responsible means renouncing some degree of profitability, renouncing profit maximization in favour of a form of satisficing, ${ }^{2}$ and making a reasonable level of profits enough to allow the business to survive comfortably. Therefore, the most challenging cases of social innovation will involve the firm's decision-makers in a trade-off between profitability and promotion of wider social benefits, a trade-off between the interests of shareholders and those of other stakeholders. Christensen and van Bever (2014) call this the capitalist's dilemma: how should managers decide, when most shareholders have short-term profitability in mind but long-term planning is the best recipe for economic development. We would suggest that this puzzle of why short-term profitability is emphasized over social impact is caused not just by an interest in quick financial returns, but also by the metrics by which we currently measure profitability and innovation. If companies and organizations were to begin measuring their social impact systematically in a manner related to universally agreed-upon global indicators (e.g. Global Reporting Initiative, United Nations Global Compact, and Social Progress Index), that would represent in itself a major innovation in measurement of organizational performance; and would thereby make a vital practical contribution to the promotion of socially responsible innovation.

\section{Conclusion}

This article explored the involvement of business in processes of social innovation - a phenomenon characterised as lacking conceptual clarity. By interweaving the key arguments in the literature we reveal the dominant constructs that characterise the role played by business in social innovation. The analysis leads us to advocate for a human-centric conceptualisation of this phenomenon. Within this view, individual business agents are proactive and morally engaged social actors. They have the creative capacity to generate new ideas, leverage a firm's relational capital and mobilise business resources to foster social progress. Economic gain, in this approach, is at best an outcome of social innovation, not its engine. Social innovation is thus portrayed as a unique way of understanding how business actors may be self-directed and self-organised around the mission of fostering social progress.

In addition, our conceptualisation is based on the notion of socially 'responsible' innovation; that is to say a concept of social innovation as an innovative activity that is intended 
by the individuals involved to bring clear social benefits or to help to address clearly identified social problems. We are not therefore adopting the term social innovation in the somewhat narrow sense of innovation in the social and legal forms of productive enterprises, a notion which can better perhaps be described as institutional innovation. The notion of 'socially responsible innovation' as both a phenomenon and a process, we argue, provides for a better connection with an evolving and increasingly complex understanding of the role of business in an increasingly broken society.

It is hoped that the efforts made in this article to clarify the core tenets of social innovation in business will be a useful resource to the social actors (and perhaps essentially business agents) who seek to accelerate change toward a more equitable distribution of the benefits of innovation, and avert the socially divisive and exclusivist agenda that traditional conceptions of innovation in business and the wider economy have tended to encourage.

\section{References}

Adams, R., Jeanrenaud, S., Bessant, J., Overy, P., \& Denyer, D. (2012). Innovating for sustainability: A systematic review of the body of knowledge. Retrieved from http://nbs.net/wp-content/uploads/NBS-Systematic-Review-Innovation.pdf

Bauer, K., \& Bakkalbasi, N. (2005). An examination of citation counts in a new scholarly communication environment. D-Lib Magazine, 11(9), Online serial.

Beall, J. (2014). Google Scholar is filled with junk science. Retrieved from https://scholarlyoa.com/2014/11/04/google-scholar-is-filled-with-junk-science/

Brown, T., \& Wyatt, J. (2010). Design Thinking for Social Innovation. Stanford Social Innovation Review, 8(1), 31-35.

Christensen, C. M., \& van Bever, D. (2014). The Capitalist's Dilemma. Harv Bus Rev, 92(6), 60-68.

Crane, A., Palazzo, G., Spence, L. J., \& Matten, D. (2014). Contesting the value of 'creating shared value'. California Management Review, 56(2), 130-153.

Djellal, F., \& Gallouj, F. (2012). Social innovation and service innovation. In H.-W. Franz, J. Hochgerner, \& J. Howaldt (Eds.), Challenge Social Innovation: Potentials for Business, Social Entrepreneurship, Welfare and Civil Society (pp. 119-137). Berlin, Heidelberg: Springer Berlin Heidelberg.

Ennes, M. (2014). What's the value of shared value? Retrieved from https://sharedvalue.org/groups/shared-value-initiativecommunity/what $\%$ E2\% $80 \% 99$ s-value-shared-value

European Commision. (2011). Empowering people, driving change: social innovation in the European Union. Retrieved from Luxembourg:

Fairweather, G. W. (1967). Methods for Experimental Social Innovation. Science, 158(3804), 1037.

Franz, H.-W., Hochgerner, J., \& Howaldt, J. (Eds.). (2012). Challenge social innovation: Potentials for business, social entrepreneurship, welfare and civil society. Verlag, Berlin, Heidelberg: Springer. 
Gatignon, H., Gotteland, D., Haon, C., \& Zimmer, J. (Eds.). (2016). Making Innovation Last: Sustainable Strategies for Long Term Growth (Vol. 2). London, UK: Palgrave Macmillan.

Howaldt, J., \& Schwarz, M. (2010). Social Innovation: Concepts, Research Fields and International Trends. In K. Henning \& F. Hees (Eds.), Studies for innovation in a modern working environment (Vol. 5): IMA/ZLW \& IfU.

Kanter, R. M. (1999). From spare change to real change. The social sector as beta site for business innovation. Harv Bus Rev, 77(3), 122-132, 210.

Martinez, F. (2014). Corporate strategy and the environment: Towards a four-dimensional compatibility model for fostering green management decisions. Corporate Governance, 14(5), 607-636.

Martinez, F. (2015). A three-dimensional conceptual framework of corporate water responsibility. Organization \& Environment, 28(2), 137-159.

McElroy, M. W. (2002). Social innovation capital. Journal of Intellectual Capital, 3(1), 30-39.

Moulaert, F., MacCallum, D., Mehmood, A., \& Hamdouch, A. (Eds.). (2013). The international handbook on social innovation: Collective action, social learning and transdisciplinary research. Cheltenham, UK; Northanpton, MA: Edward Elgar.

Moulaert, F., Martinelli, F., Swyngedouw, E., \& Gonzalez, S. (2005). Towards alternative model(s) of local innovation. Urban Studies, 42(11), 1969-1990.

Mulgan, G. (2006). The Process of Social Innovation. Innovations: Technology, Governance, Globalization, 1(2), 145-162.

Mulgan, G., Tucker, S., Ali, R., \& Sanders, B. (2007). Social Innovation: What it is, why it matters and how it can be accelerated. Skoll Centre for Social Entrepreneurship, Saïd Business School. Oxford.

Mumford, M. D. (2002). Social Innovation: Ten Cases From Benjamin Franklin. Creativity Research Journal, 14(2), 253-266.

Murray, R., Caulier-Grice, J., \& Mulgan, G. (2010). The open book of social innovation. London: National Endowment for Science, Technology and the Art.

Osburg, T., \& Schmidpeter, R. (Eds.). (2013). Social Innovation: Solutions for a Sustainable Future. Verlag, Berlin, Heidelberg: Springer.

Peattie, K., \& Morley, A. (2008). Eight paradoxes of the social enterprise research agenda. Social Enterprise Journal, 4(2), 91-107.

Phills, J. (2009). Rediscovering Social Innovation. The Fieldstone Foundation, San Diego Grantmakers. Stanford Graduate School of Business. San Diego.

Pol, E., \& Ville, S. (2009). Social innovation: Buzz word or enduring term? The Journal of Socio-Economics, 38(6), 878-885.

Porter, M. E., \& Kramer, M. R. (2011). Creating shared value: How to reinvent capitalism and unleash a wave of innovation and growth. Harv Bus Rev, 89(1/2), 62-77.

Roome, N. (2004). Innovation, global change and new capitalism: A fuzzy context for business and the environment. Human Ecology Forum, 11(3), 277-280.

Roome, N. (2012). Looking back, thinking forward: Distinguishing between weal and string sustainability. In P. Bansal \& A. J. Hoffman (Eds.), The Oxford Handbook of Business and the Natural Environment. Oxford: Oxford University Press.

Roome, N. (2013). Sustainable Development: Social Innovation at the Interface of Business, Society and Ecology. In T. Osburg \& R. Schmidpeter (Eds.), Social Innovation: Solutions for a Sustainable Future (pp. 299-308). Berlin, Heidelberg: Springer Berlin Heidelberg.

Serenko, A. (2015). Citation classics published in Knowledge Management journals. Part II: studying research trends and discovering the Google Scholar Effect. Journal of Knowledge Management, 19(6), 1335-1355. 
SPI. (2015). Social progress network: A strategic effort to use the Social Progress Index to advance social progress around the world. Retrieved from http://www.socialprogressimperative.org/network/

Torraco, R. J. (2005). Writing Integrative Literature Reviews: Guidelines and Examples. Human Resource Development Review, 4(3), 356-367. of business in social innovation. Journal of Management Development, 36(5), 681-695. 
Table 1. Representative literature on social innovation selected for review

\begin{tabular}{|c|c|c|c|c|c|}
\hline $\begin{array}{l}\text { Article } \\
\text { rank }\end{array}$ & Title & Year & Author(s) & Type of document & $\begin{array}{c}\text { Number of } \\
\text { citations* }\end{array}$ \\
\hline 1 & $\begin{array}{l}\text { Social Innovation: What it is, why it matters } \\
\text { and how it can be accelerated }\end{array}$ & 2007 & $\begin{array}{l}\text { Geoff Mulgan, Simon } \\
\text { Tucker, Rushanara Ali, Ben } \\
\text { Sanders }\end{array}$ & Working paper & 710 \\
\hline 2 & Rediscovering Social Innovation & 2009 & Jim Phills & Lecture slides & 700 \\
\hline 3 & $\begin{array}{l}\text { From spare change to real change: the social } \\
\text { sector as a beta site for business innovation }\end{array}$ & 1999 & Rosabeth M. Kanter & Journal article & 673 \\
\hline 4 & The open book of social innovation & 2010 & $\begin{array}{l}\text { Robin Murray, Julie Caulier- } \\
\text { Grice and Geoff Mulgan }\end{array}$ & Book & 476 \\
\hline 5 & Design Thinking for Social Innovation & 2010 & $\begin{array}{l}\text { Tim Brown and Jocelyn } \\
\text { Wyatt }\end{array}$ & Journal article & 432 \\
\hline 6 & Social innovation capital & 2002 & Mark W. McElroy & Journal article & 384 \\
\hline 7 & The Process of Social Innovation & 2006 & Geoff Mulgan, & Journal article & 381 \\
\hline 8 & $\begin{array}{l}\text { Social Innovation: Ten Cases From } \\
\text { Benjamin Franklin }\end{array}$ & 2002 & Michael D. Mumford & Journal article & 294 \\
\hline 9 & $\begin{array}{l}\text { Social innovation: Buzz word or enduring } \\
\text { term? }\end{array}$ & 2009 & Eduardo Pol and Simon Ville & Journal article & 287 \\
\hline 10 & Methods for Experimental Social Innovation & 1967 & George W. Fairweather & Journal article & 260 \\
\hline 11 & $\begin{array}{l}\text { Social Innovation: Concepts, Research Fields } \\
\text { and International Trends }\end{array}$ & 2010 & $\begin{array}{c}\text { Jürgen Howaldt, Michael } \\
\text { Schwarz, Klaus Henning and } \\
\text { Frank Hees }\end{array}$ & Book chapter & 240 \\
\hline
\end{tabular}

* The citation data are based on Google Scholar (collected on 21/09/2016) 
Table 2. Synthesis of the key arguments made about social innovation in business

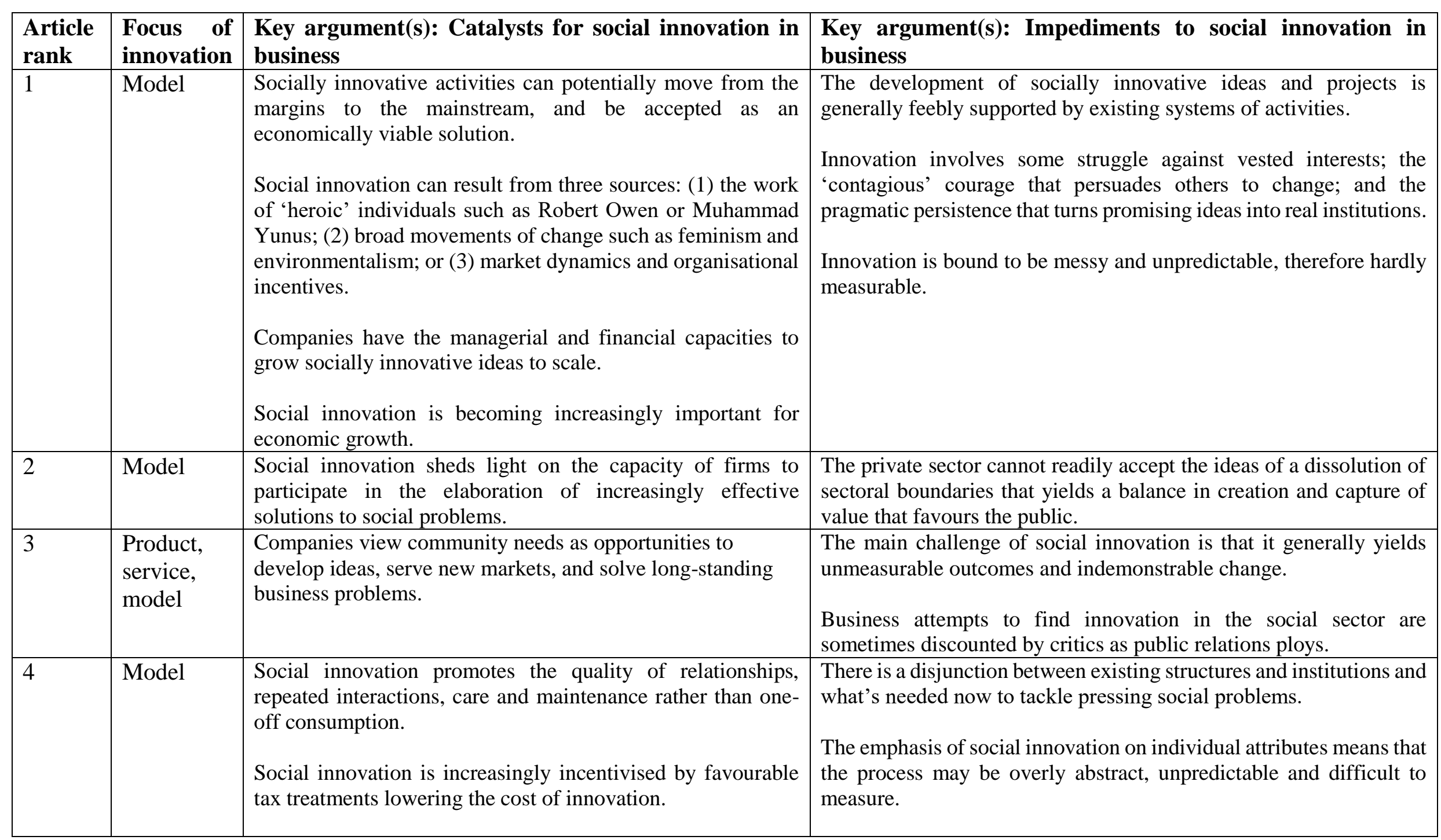




\begin{tabular}{|c|c|c|c|}
\hline & & $\begin{array}{l}\text { Social innovation benefits from the commitment of a } \\
\text { multitude of innovation drivers and intermediaries, often } \\
\text { known as innovation incubators, hubs or champions. }\end{array}$ & \\
\hline 5 & Model & $\begin{array}{l}\text { Mobilisation of human capital toward a desired end goal } \\
\text { Closer connection with local communities will help business } \\
\text { capture a range of unmet needs }\end{array}$ & $\begin{array}{l}\text { Social innovation may be seen as a risk to which business agents may } \\
\text { be averse insofar as they generally fear failure and experimentation. }\end{array}$ \\
\hline 6 & Model & $\begin{array}{l}\text { Social innovation capital as the collective capacity of a firm to } \\
\text { innovate is the most valuable form of intellectual capital. } \\
\text { The management of social innovation capital may improve the } \\
\text { rate and quality of innovation in a firm, as well as their } \\
\text { competitive stance in the marketplace. } \\
\text { Social innovation must focus on enabling independent, self- } \\
\text { directed learning for individuals, community formation and } \\
\text { support for groups, and the consideration of community-made } \\
\text { knowledge in the form knowledge processing and integration } \\
\text { affairs of their firms. }\end{array}$ & $\begin{array}{l}\text { The literature fails to differentiate between one type of innovation } \\
\text { process and another in terms that might ascribe different levels of } \\
\text { value, or purpose, to different kinds of innovations. }\end{array}$ \\
\hline
\end{tabular}

*Postprint of: Martinez, F., O'Sullivan, P., Smith, M., \& Esposito, M. (2017). Perspectives on the role of business in social innovation. Journal of Management Development, 36(5), 681-695. 


\begin{tabular}{|c|c|c|c|}
\hline 8 & Model & $\begin{array}{l}\text { The production resulting from social innovation may vary } \\
\text { with regard to their breadth and impact, ranging from 'micro- } \\
\text { innovations' to 'great innovation' } \\
\text { Processes of social innovation might well constitute a unique } \\
\text { way of understanding how individuals (including business } \\
\text { actors) self-organise around a social mission that is not bound } \\
\text { with economic objectives. }\end{array}$ & $\begin{array}{l}\text { The field of social innovation has received little attention in academic } \\
\text { research. } \\
\text { Social innovation in business is impeded where capital is } \\
\text { monopolized by urban elites or government. }\end{array}$ \\
\hline 9 & Model & $\begin{array}{l}\text { The creation of new ideas promoted by social innovation is at } \\
\text { the centre of the improvement of living conditions. } \\
\text { Social innovation highlights the production of many new ideas } \\
\text { that (at least initially) are not created with the purpose of } \\
\text { making money. }\end{array}$ & $\begin{array}{l}\text { Some commentators consider social innovation no more than a buzz } \\
\text { word or passing fad that is too vague to be successfully applied to } \\
\text { academic scholarship. }\end{array}$ \\
\hline 10 & $\begin{array}{l}\text { Service, } \\
\text { model }\end{array}$ & $\begin{array}{l}\text { Social innovation enables business to increase its knowledge } \\
\text { of the environment and communities in which it operates. } \\
\text { In building close relationships with communities, the } \\
\text { economic aims of a business project may sometimes be } \\
\text { outstripped by the need to provide social services to the } \\
\text { communities. } \\
\begin{array}{l}\text { Social innovation requires experiments until the new model is } \\
\text { widely adopted. }\end{array}\end{array}$ & $\begin{array}{l}\text { Social innovation may often be impeded by the inability to secure } \\
\text { administrative and financial approval. }\end{array}$ \\
\hline 11 & Model & $\begin{array}{l}\text { Social innovation require innovators to look beyond } \\
\text { technological solutions to consider any ideas that create and } \\
\text { contributes to public values that are considered to be } \\
\text { important. } \\
\text { The increasing importance of management and work-related } \\
\text { aspects of innovative capacity means that a firm's } \\
\text { 'managerial' competences are an asset to sustained social } \\
\text { innovation projects. }\end{array}$ & $\begin{array}{l}\text { Social innovation is weakly conceptualised, sue to the dominance of } \\
\text { grey, policy-oriented literature. }\end{array}$ \\
\hline
\end{tabular}




\begin{tabular}{|l|l|l|}
\hline & $\begin{array}{l}\text { Social innovation brings together people from many different } \\
\text { walks of life, not only science and business, who may have } \\
\text { varied interpretations of what constitutes socially desirable } \\
\text { effects and outcomes of social innovation. }\end{array}$ & \\
\hline
\end{tabular}

${ }^{1}$ One of the pitfalls of a stakeholder approach being that often the interests of different stakeholders point in entirely opposite directions, hence it is difficult to conceive of strategies that maximize benefits for all stakeholders. Consider for example the interests of workers and shareholders in the tobacco industry on the one hand, with the interests of passive smokers on the other.

${ }^{2}$ We are aware that the term satisficing was initially used with a similar meaning but in a somewhat different context by Herbert Simon in his discussions of the behavioral theory of the firm. Simon was discussing the implications of the divorce of ownership and management and the implications of this for managerial motivation and behaviour when taking managerial decisions. 